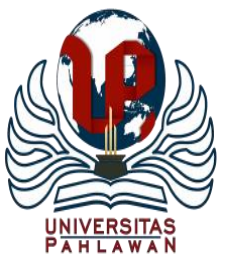

Jurnal Abdidas Volume 1 Nomor 3 Tahun 2020 Halaman 149 - 156

JURNAL ABDIDAS

Community Development Service on Educational and Health Sciences

http://abdidas.org/index.php/abdidas

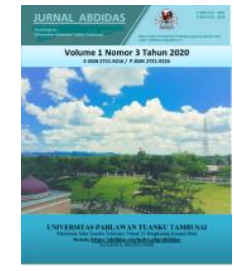

\title{
Lokakarya Sistem Manajemen Belajar Berbasis Schoology Bagi Guru Sekolah Dasar di Kabupaten Sukoharjo
}

\author{
Muhamad Taufik Hidayat ${ }^{1}$ \\ Pendidikan Guru Sekolah Dasar, Universitas Muhammadiyah Surakarta, Jawa Tengah, Indonesia ${ }^{1}$ \\ E-mail : mt.hidayat@ums.ac.id ${ }^{1}$
}

\begin{abstract}
Abstrak
Adapun tujuan yang ingin dicapai melalui kegiatan pengabdian ini adalah memberikan lokakarya penggunaan LMS Schoology bagi guru-guru SD di Sukoharjo. Muara dari kegiatan ini adalah untuk meningkatkan keterampilan penggunaan Schoology sebagai LMS bagi guru SD. Khalayak sasaran yang dilibatkan adalah guru SD anggota Persatuan Guru Republik Indonesia (PGRI) Sukoharjo sebanyak 93 orang. Kegiatan pengabdian kepada masyarakat ini dilaksanakan dalam bentuk pelatihan dengan tahapan pertama berupa informasi, tanya jawab, dan diskusi. Sementara tahapan berikutnya berupa latihan dan praktek. Berdasarkan pelaksanaan kegiatan pengabdian masyarakat ini, dapat ditarik kesimpulan bahwa: pertama, lokakaya ini mampu meningkatkan pengetahuan dan keterampilan peserta guru-guru SD di Sukoharjo. Lokakarya ini juga menghasilkan produk pengembangan course / kelas online oleh peserta. Peserta dapat mengimplementasikan course Schoology tersebut di SD masing-masing. Lokakarya ini dianggap berhasil karena $100 \%$ peserta hadir secara parsial, $90 \%$ peserta mengikuti lokakarya secara penuh, serta $90 \%$ peserta bisa membuat course beserta kontennya dengan baik dan lengkap.
\end{abstract}

Kata kunci: learning management system, schoology, guru sekolah dasar, e-learning

\section{Abstract}

The objectives of this community service were to provide workshops on the use of LMS Schoology for elementary school teachers in Sukoharjo. The goal of this activity was to improve the skills to use Schoology as an LMS for elementary school teachers. The audience in this activity were elementary school teachers of PGRI (United Teacher of Republic of Indonesia) Sukoharjo as many as 93 teachers. This community service were carried out in the form of training with the first stage in the form of information, questions and answers, and discussions. While the next stage was training and practice. Based on the implementation of these community service activities, it can be concluded that: first, this workshop can improved the knowledge and skills of participants. The workshop also produced online course / class. Participants can implement the Schoology course in their elementary schools. The workshop was successful because $100 \%$ of participants attended in partial, $90 \%$ of participants attended in full, and $90 \%$ of participants were able to make the course and its contents well and completely.

Keywords: learning management system, schoology, elementary school teachers, e-learning

Copyright (c) 2020 Muhamad Taufik Hidayat

$\triangle$ Corresponding author :

Address : Kartasura, Sukoharjo, Jawa Tengah

ISSN 2721 - 9224 (Media Cetak)

Email : mt.hidayat@ums.ac.id

ISSN 2721- 9216 (Media Online)

Phone : 085741124375

DOI: https://doi.org/10.31004/abdidas.v1i3.34 


\section{PENDAHULUAN}

Pembelajaran di Sekolah Dasar (SD) merupakan salah satu tahap pembelajaran yang penting karena akan berpengaruh pada pembelajaran di jenjang berikutnya. Dalam proses belajar mengajar di SD, guru seringkali menghadapi berbagai kendala sehingga tujuan pembelajaran tidak tercapai secara optimal. Kendala ini harus segera ditangani dengan baik, salah satunya dengan bantuan media pembelajaran. Media pembelajaran dapat memperjelas penyajian pesan dan informasi sehingga dapat memperlancar dan meningkatkan proses serta hasil belajar. Selain itu media pembelajaran dapat meningkatkan dan mengarahkan perhatian peserta didik sehingga dapat menimbulkan motivasi belajar, interaksi yang lebih langsung antara peserta didik dengan lingkungannya, dan kemungkinan peserta didik untuk belajar mandiri sesuai dengan kemampuan dan minatnya. Media pembelajaran juga dapat mengatasi keterbatasan indera, ruang, dan waktu.

Penguasaan guru SD akan Teknologi Informasi dan Komunikasi (TIK) sangat berpengaruh sekali terhadap penguasaan guru SD dalam penggunaaan media pembelajaran. Hal ini dikarenakan banyak media pembelajaran kontemporer yang berbasis TIK. Oleh sebab itu, kemampuan guru SD dalam menggunakan perangkat TIK sangat penting. Media TIK yang dapat digunakan oleh guru dalam pembelajaran tentunya banyak sekali. Banyak media online maupun offline, software maupun hardware, dan dapat digunakan guru sebagai media pembelajaran. Media online misalnya guru sudah menggunakan fasilitas e-mail untuk sarana pengumpulan tugas, blog untuk memposting bahan-bahan ajar agar memudahkan peserta didik mendapatkan materi pembelajaran dan membuat berbagai media pembelajaran lainnya.

Wawancara dengan beberapa informan guru SD di Sukoharjo, mengungkap bahwa sebagian besar guru telah memiliki laptop dan difasilitasi proyektor atau LCD (Liquid Crystal Display). Ditambah lagi, perangkat TIK tersebut kurang dimanfaatkan sebagai media pembelajaran, bahkan lebih sering mangkrak. Penggunaan perangkat TIK hanya ketika dibutuhkan dan mendesak saja. Padahal seorang guru SD harus lebih memanfaatkan media tersebut untuk membantu meningkatkan kualitas pembelajaran.

Penguasaan sistem manajemen pembelajaran (LMS) berbantu teknologi menjadi salah satu keterampilan penting bagi guru SD untuk membantu peserta didik SD mencapai tujuan pembelajaran. Salah satu LMS yang potensial sebagai sarana penciptaan media pembelajaran yang menarik adalah Schoology. Schoology merupakan sebuah LMS yang memungkinkan guru SD untuk melakukan pembelajaran bauran (blended learning) di SD. Pembelajaran bauran akan mulai sering diaplikasikan mengingat massifnya penggunaan gadget pada peserta didik SD. Selain itu, pembelajaran bauran juga bisa mengakomodir peserta didik dan guru SD yang dituntut untuk mobile.

Sejauh ini pelatihan atau lokakarya LMS berbasis Schoology beberapa kali dilakukan di Indonesia (Arsini, 2018; Aswandi, Mardiyanto, Amri, \& Mahdi, 2018; Rosy, Ranu, Nugraha, \& Handini, 2018; Sujanem, 2012; Suparman \& Paiki, 
2019). Namun demikian pelatihan tersebut hanya terbatas pada guru-guru sekolah menengah. Hal ini menyisakan suatu kebutuhan lokakarya bagi guruguru SD. Dengan lokakarya LMS berbasis Schoology, diharapkan guru-guru SD di Sukoharjo mampu memanfaatkan Schoology sebagai LMS yang menarik dan efektif demi tercapainya tujuan pembelajaran di SD di era industri 4.0.

Dari analisis situasi dapat diketahui bahwa guru-guru SD di Sukoharjo mengalami kesulitan dalam memanfaatkan fasilitas sekolah seperti laptop dan wifi guna menunjang aktivitas pembelajaran. Guru-guru SD di Sukoharjo perlu dibekali keterampilan dalam memanfaatkan teknologi salah satunya dengan penggunaan LMS Schoology. Dari latar belakang di atas, maka rumusan permasalahan yang dapat ditarik adalah bagaimana keefektifan lokakarya LMS berbasis Schoology bagi guru-guru SD di Sukoharjo dalam meningkatkan keterampilan mengajar?

Adapun tujuan yang ingin dicapai melalui kegiatan pengabdian ini adalah memberikan lokakarya penggunaan LMS Schoology bagi guruguru SD di Sukoharjo.

Hasil kegiatan pengabdian pada masyarakat ini akan memberikan kontribusi positif terhadap usaha peningkatan kualitas pendidikan, khususnya keterampilan guru dalam mengajar di jenjang SD. Secara eksplisit kontribusi hasil kegiatan pengabdian masyarakat ini dapat dijabarkan sebagai berikut.

1. Para guru SD di Sukoharjo memperoleh ilmu tentang penggunaan LMS Schoology sehingga dapat meningkatkan kemampuan guru dalam mengolah materi pembelajaran untuk dapat dipahami peserta didiknya.

2. Program ini juga dapat membantu guru SD di Sukoharjo mengatasi masalah belajar peserta didik SD dengan berbantu LMS.

Target Luaran dari kegiatan pengabdian ini adalah

1. Guru SD yang terampil memakai LMS Schoology

2. Artikel kegiatan pengabdian masyarakat ini dimuat dalam koran lokal (Jawa Tengah atau Sukoharjo) serta jurnal pengabdian masyarakat nasional.

\section{METODE}

\section{Khalayak Sasaran}

Muara dari kegiatan ini adalah untuk meningkatkan keterampilan penggunaan Schoology sebagai LMS bagi guru SD. Terkait dengan hal ini, khalayak sasaran yang strategis dan tepat untuk dilibatkan dalam kegiatan ini adalah guru SD anggota PGRI Sukoharjo sebanyak 93 orang.

\section{Kerangka Pemecahan Masalah}

Menindaklanjuti keterbatasan dan kesulitan yang dialami guru-guru SD di Sukoharjo dalam memanfaatkan teknologi sebagai sarana mengajar di kelas maka disusunlah kerangka pemecahan masalah sebagai berikut: 


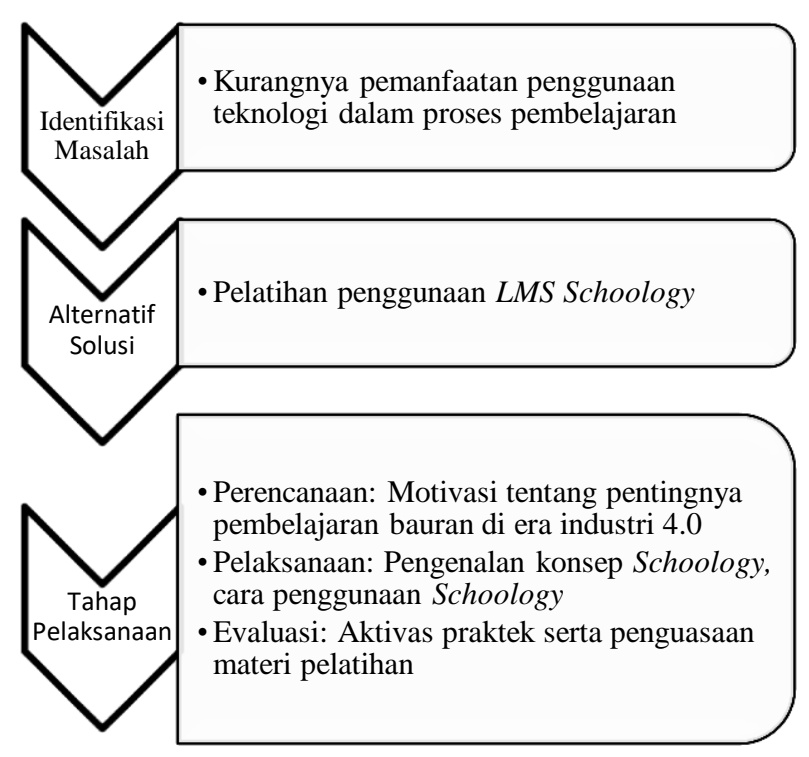

Gambar 1. Bagan Kerangka Berfikir

\section{Keterkaitan}

Instansi-instansi yang terkait dengan kegiatan ini adalah sebagai berikut.

1. PGRI Kabupaten Sukoharjo dengan para gurunya mendapat pelatihan langsung dalam kegiatan ini. Pengetahuan dan keterampilan guru dalam kaitannya dengan pemanfaatan LMS dalam mengajar akan meningkat. Harapannya dapat menjalankan pembelajaran bauran di SD.

2. Universitas Muhammadiyah Surakarta yang merupakan instansi dari tim pengabdian yang menyediakan sumber dana dan fasilitator untuk berlangsungnya kegiatan.

\section{Tahapan Kegiatan}

Kegiatan pengabdian kepada masyarakat ini dilaksanakan dalam bentuk pelatihan dengan tahapan sebagai berikut:

1. Informasi, tanya jawab, dan diskusi

Metode ini dimaksudkan untuk memperdalam pemahaman dan wawasan guru mengenai motivasi pentingnya penguasaan IPTEK (Ilmu Pengetahuan dan Teknologi) bagi guru SD, khususnya mengenai TIK. Pemberian informasi melalui diberikan oleh narasumber dari dosen tim pengabdian.

\section{Latihan dan Praktek}

Metode ini dimaksudkan untuk merealisasikan teori yang diperoleh melalui infomasi, tanya jawab dan diskusi, sehingga keterampilan guru pembina dapat ditingkatkan. Dalam pelaksanaannya, peserta secara individu dibantu untuk registrasi akun Schoology dibantu oleh tim pengabdian. Peserta juga dilatih untuk mengembangkan sendiri pembelajaran baurannya.

Tabel 1. Jadwal Pelaksanaan Lokakarya

\begin{tabular}{|c|c|}
\hline Waktu & Materi \\
\hline $07.00-08.00$ & $\begin{array}{l}\text { Pengantar Blended Learning, LMS dan } \\
\text { Rumah Belajar. }\end{array}$ \\
\hline $08.00-09.00$ & $\begin{array}{l}\text { 1. Pembuatan dan Penyetelan Akun } \\
\text { 2. Pembuatan dan Penyetelan Kelas }\end{array}$ \\
\hline $09.00-10.00$ & $\begin{array}{l}\text { Penyiapan Konten: } \\
\text { 1. Pembuatan dan Pengelolaan Page } \\
\text { 2. Pengorganisasian Materi Mata } \\
\quad \text { Pelajaran }\end{array}$ \\
\hline $10.00-11.00$ & Diskusi (Q\&A) \\
\hline $11.00-12.00$ & $\begin{array}{l}\text { Pengisian Konten: } \\
\text { 1. Unggah Materi Pelajaran dan Konten } \\
\text { 2. Memasukkan peserta didik dan } \\
\text { Pengelolaan Kelompok Belajar }\end{array}$ \\
\hline $13.00-14.00$ & $\begin{array}{l}\text { Pengelolaan Pembelajaran: } \\
\text { 1. Memposting Pengumuman kepada } \\
\text { peserta didik } \\
\text { 2. Membuat Forum Diskusi dan Rubrik } \\
\text { 3. Memberi Nilai/Feedback Diskusi }\end{array}$ \\
\hline $14.00-15.00$ & $\begin{array}{l}\text { Pengelolaan Pembelajaran: } \\
\text { 1. Membuat Tugas } \\
\text { 2. Memberi Nilai/Feedback Tugas } \\
\text { 3. } \quad \text { Membuat Aneka Tes dan Kuis }\end{array}$ \\
\hline $15.00-16.00$ & $\begin{array}{l}\text { Pengelolaan Pembelajaran: } \\
\text { 1. Memberi Nilai/Feedback Tes dan Kuis } \\
\text { 2. Menambah Grade pada Gradebook } \\
\text { dan Mengekspor Hasil Nilai }\end{array}$ \\
\hline $16.00-16.15$ & Refleksi dan Penutup \\
\hline
\end{tabular}


Hal-hal yang harus dipersiapkan peserta lokakarya antara lain; (1) laptop beserta charger laptop (2) kuota internet (3) membuat akun e-mail baru di google mail dan mencatat password-nya. (4) menyiapkan materi pelajaran dalam format pdf/ppt/word minimal dua pertemuan (5) mengunduh minimal satu video materi di situs Rumah Belajar atau Youtube (6) peserta tidak diperbolehkan terlambat dan harus mengikuti semua sesi lokakarya.

\section{Evaluasi}

Ada dua aspek yang dievaluasi pada kegiatan ini:

1. Aktivitas peserta selama pelatihan berlangsung. Keberhasilan dapat dilihat dari kehadiran dan aktivitas peserta selama kegiatan baik bertanya, menjawab pertanyaan dan berdiskusi. Kegiatan dikatakan berhasil jika minimal $80 \%$ sasaran hadir, dan minimal $80 \%$ peserta yang hadir mengikuti kegiatan secara penuh.

2. Tingkat penguasaan penggunaan Schoology. Dilihat dari akun dan course yang dibuat oleh guru-guru peserta.

\section{HASIL DAN PEMBAHASAN}

\section{Pembuatan dan Penyetelan Akun}

Peserta diminta membuka website Schoology. Setelah itu peserta sign up sebagai Instructor dengan menuliskan nama lengkap, $e$ mail, dan password. Selanjutnya peserta memasukkan negara, kota, kode pos, dan afiliasi. Jika nama afiliasi belum terdaftar, maka peserta diminta memasukkan nama afiliasi dengan klik "Request to Add your School".
Setelah peserta sudah membuat akun, kemudian peserta diminta mengatur akun. Peserta mengubah foto dengan mengungah foto masingmasing. Peserta juga mengganti informasi: nama, e-mail, waktu, dan sebagainya di "Account Setting". Peserta diingatkan untuk menyimpan perubahan dengan klik "Save Change".

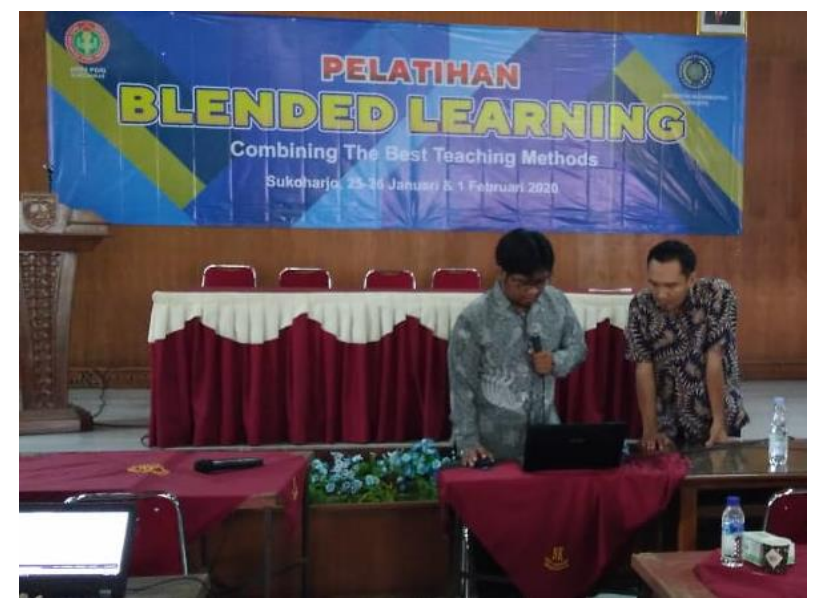

Gambar 2. Pelatih Memaparkan Materi Lokakarya

\section{Pembuatan dan Penyetelan Kelas}

Setelah peserta mendaftar dan mensetting akun di Schoology sebagai guru, selanjutnya peserta membuat course atau kelas. Peserta membuat kelas dengan klik "Create a Courses". Kemudian peserta mengisi nama mata pelajaran, nama rombongan belajar, konsentrasi mata pelajaran, serta level. Peserta kemudian diminta memperhatikan "Access Code" yang yang nanti akan diberikan pada peserta didik. Peserta selanjutnya diminta mengatur kelas yang telah dibuat dengan menambahkan gambar kelas, deskripsi singkat, dan lokasi waktu pembelajaran. Peserta juga dibimbing cara mengubah nama course yang telah di buat. 


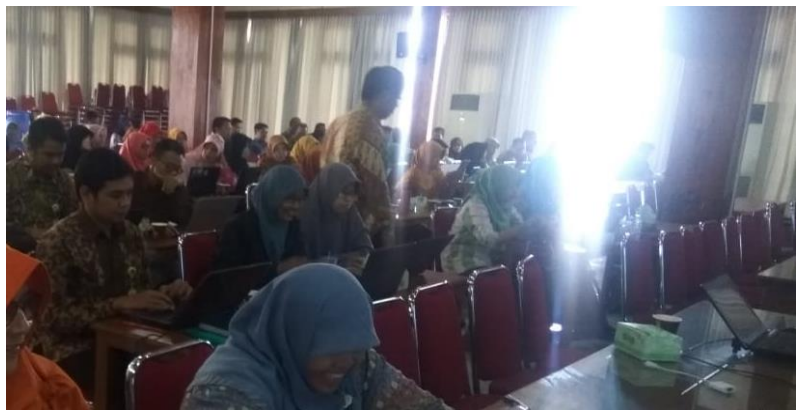

Gambar 3. Suasana Pendampingan Peserta Oleh Asisten Pelatih

\section{Penyetelan dan Melihat Buku Nilai}

Selanjutnya peserta diminta membuka kelas dan memilih "Grade Setup". Peserta mengisi Category "Name", misal "Presensi", kemudian memilih "Calculated by": Percent, pada "Drop Lowest" diabaikan. Peserta melakukan hal yang sama untuk membuat kategori penilaian lain. Selanjutnya peserta mengisi persentase pada tiap kategori. Selanjutnya peserta menyetel "Grading Periods \& Final Wight" serta menambahkan atau membuat Skala Penilaian.

\section{Mengembangkan dan Mengelola Konten Bahan} Ajar

Pembuatan Page (laman). Pembuatan laman ini digunakan sebagai kata pembuka dan motivasi dalam pembelajaran. Peserta diminta kembali ke laman "Courses", kemudian menambahkan laman. Setelah muncul editor untuk membuat laman peserta mengetikkan judul halaman, isi laman (gambar, video, dan lampiran yang diperlukan). Jika peserta ingin mengedit,, memindah, menyalin ke kelas lain atau bahkan menghapus laman, maka peserta membuka tanda gear sebelah kanan.

Pembuatan Folder. Peserta membuka courses, selanjutnya klik membuat folder dengan klik "add Folder". Setelah itu, peserta mengisi kotak-kotak yang tersedia. Peserta mengisi nama folder, deskripsi singkat, tanggal, serta memilih warna folder dan availability. Selanjutnya peserta mengulang langkah hingga tersedia folders untuk semua maple. Peserta yang akan mengedit, memindah, atau bahkan menghapus folder, diminta mengeklik icon gear di sebelah kanan folder tersebut. Setelah folder-folder sudah siap, peserta dapat mengisi dengan konten-konten bahan ajar dan sumber belajar.

Mengunggah slide presentasi. Peserta memilih folder yang akan diisi materi perkulihan dengan klik "Add Materials", "Files/Links/External Tools", memilih "File", "Attach Files" kemudian klik "Add". Untuk memasukkan link pada folder pertemuan 1 , peserta mengeklik folder yang akan diisikan materi perkulihan. Ulangi proses di atas untuk seluruh folder.

Memasukkan Peserta Didik. Peserta menginformasikan 13 digit kode akses dari courses kepada minimal 4 orang peserta pelatihan (setiap peserta pelatihan akan mendapatkan kode akses atas 4 Mapel berbeda). Peserta masuk ke courses dengan klik "Courses", lalu "My Courses", "Manage Courses", "Join a Course" dan memasukkan 13 digit kode akses yang diterima lalu klik "Join". Peserta mengecek jumlah peserta didik di bagian "Member" kolom sebelah kiri.

Membuat Co-Administrator dan Mengelola "Members". Peserta mengangkat asisten dalam mengelola kelas atau admin tambahan dengan klik "Members" dan memilih peserta didik atau guru lain. Peserta mengeklik pengaturan gambar icon 
gear di sebelah kanan kemudian memilih "make admin". Member yang diplot admin hanya yang memiliki akun instructor bukan student. Peserta bisa mengeluarkan peserta didik dalam course dengan memilih "Unenroll", mengirim pesan pribadi ke peserta didik ("send massage"), serta melihat tampilan courses dengan berpura-pura sebagai peserta didik tertentu ("preview courses").

Membuat Grup Kelas pada Menu Members. Peserta mengeklik "Members", "Organize members into Grading Group", kemudian "Grading Group". Setelah muncul dialog box "Edit Grading Group", peserta mengetik nama group pada "Group Name", dan memilih anggota group dengan cara mengeklik nama peserta didik dan "Create Grading Group".

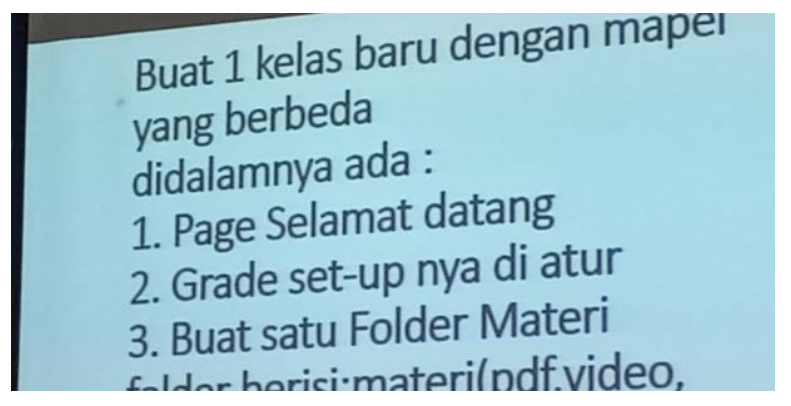

Gambar 4. Slide Materi Lokakarya

\section{Pengelolaan Pembelajaran}

Memposting Informasi atau Pengumuman ke peserta didik. Peserta diminta mengeklik Logo Schoology, "Post", dan memilih "Update". Kemudian peserta menuliskan pengumuman. Pada bagian icon peserta mencari sasaran pengumuman. Terakhir, peserta mempublikasikan pengumuman.

Membuat Forum Diskusi dan Rubrik. Peserta kembali ke courses kemudian memilih tempat dimana forum diskusi akan dibuat. Peserta menulis judul diskusi, pertanyaan diskusi, menambah lampiran, menentukan waktu teggat diskusi, mencentang "Enable Grading", menentukan kategori penilaian, menentukan skala/rubrik. Setelah topik sudah selesai dibuat, peserta sebagai "peserta didik" mensubmit diskusi dari Mapel yang diikuti. Sebagai Instructor, peserta memberikan penilaian diskusi yang masuk.

Membuat Tugas. Peserta diminta membuka courses. Selanjutnya peserta memilih "Add Materials", dan "Assigment". Peserta mengetik judul tugas, deskripsi, menambah lampiran, menentukan tanggal batas waktu pengumpulan, menentukan kategori, menentukan skala/rubrik, dan mengelik "Create". Kemudian peserta mengumpulkan tugas dari courses yang diikuti. Peserta diminta membuka courses dan memeriksa tugas dari courses yang diampu. Peserta juga diminta memberi feedback dan nilai dari tugas.

Menambah grade penilaian dan mengekspor hasil nilai. Peserta diminta kembali ke course. Selanjutnya diminta mengeklik "Gradebook", tanda plus $(+)$ di sebelah kanan, dan memilih "Add Grade Column", jika peserta ingin menambah grade untuk penilaian. Kemudian peserta mengeksport hasil nilai dari Schoology ke Microsoft Excel dengan klik tanda titik tiga, kemudian pilih Export. Setelah itu masuk ke "Choose Export Type", pilih "Gradebook as CSV", dan klik "Next". Peserta diminta membuka hasil export, untuk mengatur kolom pada Microsoft Excel. 


\section{Evaluasi}

Lokakarya ini dianggap berhasil karena kehadiran peserta mencapai 100\% dengan 90\% peserta mengikuti lokakarya secara penuh. Peserta yang tidak mengikuti secara penuh dikarenakan alasan tidak membawa laptop, tidak bisa terkoneksi dengan internet, atau menyerah karena tertinggal jauh dengan peserta lain. Sebagian besar peserta aktif bertanya pada pemateri maupun asisten pemateri. Terakhir, $90 \%$ peserta bisa membuat course beserta kontennya dengan baik dan lengkap.

\section{SIMPULAN}

Berdasarkan pelaksanaan kegiatan pengabdian masyarakat ini, dapat ditarik kesimpulan bahwa: pertama, lokakaya ini mampu meningkatkan pengetahuan dan keterampilan peserta guru-guru SD di Sukoharjo. Lokakarya ini juga menghasilkan produk pengembangan course / kelas online oleh peserta. Peserta dapat mengimplementasikan course Schoology tersebut di SD masing-masing. Lokakarya ini berhasil karena kehadiran peserta 100\%, 90\% peserta mengikuti lokakarya secara penuh, serta $90 \%$ peserta bisa membuat course beserta kontennya dengan baik dan lengkap.

\section{DAFTAR PUSTAKA}

Arsini, A. (2018). Penguatan Kompetensi dan Keterampilan Guru Madrasah Se-Kota Semarang dalam Mengembangkan "Web Based Assesment" Menggunakan Schoology. Dimas: Jurnal Pemikiran Agama Untuk Pemberdayaan, 17(2), 277. https://doi.org/10.21580/dms.2017.172.2430
Schoology Bagi Guru-Guru Sekolah Muhammadiyah Kota Lhokseumawe. In Proceeding Seminar Nasional Politeknik Negeri Lhokseumawe (Vol. 1, pp. C87-C90). https://doi.org/10.17605/OSF.IO/P4YQ5

Rosy, B., Ranu, M. E., Nugraha, J., \& Handini, H. T. (2018). Pelatihan Media Pembelajaran Berbasis E-Learning, Schoology Bagi Guru SMK Program Keahlian Administrasi Perkantoran Di Kabupaten Jombang Jawa Timur. Jurnal Pemberdayaan Masyarakat Madani (JPMM), 2(2), 174-185. https://doi.org/10.21009/jpmm.002.2.02

Sujanem, R. (2012). Pengembangan Modul Fisika Kontekstual Interaktif Berbasis Web untuk Meningkatkan Pemahaman Konsep dan Hasil Belajar Fisika Siswa SMA di Singaraja. Jurnal Nasional Pendidikan Teknik Informatika (JANAPATI), 1(2), 103. https://doi.org/10.23887/janapati.v1i2.9825

Suparman, A. R., \& Paiki, F. F. (2019). Pelatihan Penggunaan Media ICT Online bagi Guru, Orang Tua dan Siswa SMP IT Insan Mulia Manokwari berupa Edmodo dan Schoology. Jurnal Abdimas BSI: Jurnal Pengabdian Kepada Masyarakat, 2(2), 251-261. https://doi.org/10.31294/jabdimas.v2i2.5814

Aswandi, Mardiyanto, A., Amri, \& Mahdi. (2018). Pelatihan Media E-Learning Berbasis 